Dansk Ultralyddiagnostisk Selskab

\title{
ULTRASOUND UPDATE 2019
}

\section{Tórshavn, Færøerne 20-21 Juni 2019}

Kurset var arrangeret af DUDS og DAUS i samarbejde med WFUMB og med endorsement fra EFSUMB. Alle foredrag vil i nær fremtid blive lagt ud på nævnte foreningers hjemmesider, hvorfra de frit kan tilgås. Det blev til to intense ultralyd dage med foredrag og hands-on for de 56 deltagere, fra Danmark, Norge og Færøerne, overvejende praktiserende læger, som også var kursets primære målgruppe. Undervisningen og hands-on øvelserne fokuserede på POCUS (point-of-care ultrasound). Velvillighed og indsats fra tre ultralydfirmaer, GE Healthcare, Philips Healthcare og Siemens-Healthineers gjorde det muligt at gennemføre hans-on på hele seks opstillinger.

Kursusledelsen bestod af Djóni Sandberg Jensen, Rógvi Winthereig Rasmussen, Thomas Løkkegaard (DAUS), Bjørn Skjoldbye (DUDS) og Christian Pállson Nolsøe (WFUMB). Foredragsholderne bestod, ud over kursusledelsen, af kendte navne fra WFUMB's bestyrelse og komiteer, som Dieter Nürnberg (D), Seung H Kim (Kor), Christina Chammas (Brasilien), Adrian Goudie, Hassan Gharbi (Tunis), Sue Westerway (Australien), Jaques

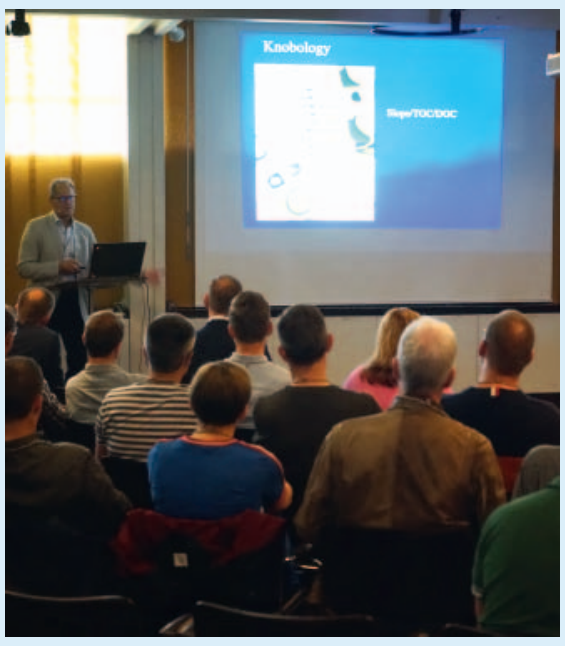

WFUMB President. Christian Nolsøe.

Abramowicz (USA) og Odd Helge Gilja (Norge). Tak til jer alle. Christian Nolsøe fortjener at blive nævnt særskilt i denne anledning, da idé såvel som arbejdet med at samle den internationale skare af prominente undervisere er hans fortjeneste. Kurset blev da også vel modtaget, både af deltagerne og af Færøerne, der kvitterede med

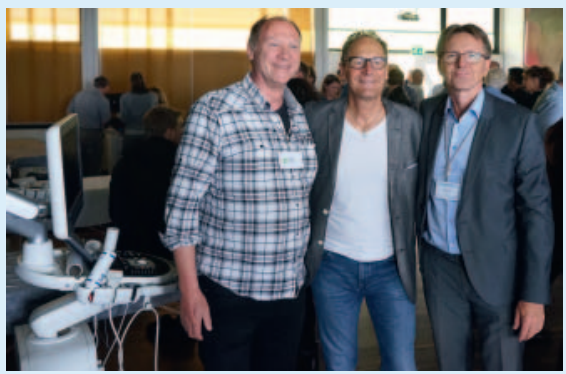

Niels Kolthoff, Christian Nolsøe og Odd Helge Gilja.

en fin officiel reception med Tórshavns borgmester som vært. Midsommerens lys over den storslåede natur i denne del af Rigsfællesskabet er selvfølgelig med til med til at give et lærerigt og oplevelses rigt besøg en fantastisk ramme. Vi ser frem til et fortsat samarbejde med vores færøske kolleger og håber at kunne byde velkommen til nye færøske medlemmer af DUDS.

Bjørn Skjoldbye og Christian Nolsøe. 